\title{
Phosphorus Availability Determines the Response of Tundra Ecosystem Carbon Stocks to Nitrogen Enrichment
}

\author{
Lorna E. Street ${ }^{1,2}$ Nora Mielke, ${ }^{1}$ and Sarah J. Woodin ${ }^{1 *}$
}

\begin{abstract}
${ }^{1}$ School of Biological Sciences, University of Aberdeen, St Machar Drive, Aberdeen AB24 3UU, UK; ${ }^{2}$ Present address: School of Geosciences, University of Edinburgh, The King's Buildings, Alexander Crum Brown Road, Edinburgh EH9 3FF, UK
\end{abstract}

\begin{abstract}
Northern permafrost soils contain important carbon stocks. Here we report the long-term response of carbon stocks in high Arctic dwarf shrub tundra to short-term, low-level nutrient enrichment. Twenty years after experimental nitrogen addition, carbon stocks in vegetation and organic soil had almost halved. In contrast, where phosphorus was added with nitrogen, carbon storage increased by more than $50 \%$. These responses were explained by changes in the depths of the moss and organic soil layers. Nitrogen apparently stimulated decomposition, reducing carbon stocks, whilst phosphorus and nitrogen co-stimulated moss productivity, increasing organic matter accumulation. The al-
\end{abstract}

tered structure of moss and soil layers changed soil thermal regimes, which may further influence decomposition of soil carbon. If climate warming increases phosphorus availability, any increases in nitrogen enrichment from soil warming or expanding human activity in the Arctic may result in increased carbon sequestration. Where phosphorus is limiting in tundra areas, however, nitrogen enrichment may result in carbon loss.

Key words: moss; nutrient; fertilisation; decomposition; productivity; soil organic matter; soil respiration; cellobiohydrolase; ammonium; nitrate.
Received 8 June 2017; accepted 21 November 2017; published online 18 December 2017

Electronic supplementary material: The online version of this article (https://doi.org/10.1007/s10021-017-0209-x) contains supplementary material, which is available to authorized users.

Data access The data from this project are available at Woodin S, Street L. 2017. Soil and vegetation parameters from re-visitation of fertilisation experiment at Ny-Ålesund, Svalbard. Polar Data Centre; British Antarctic Survey, Natural Environment Research Council, Cambridge, CB3 OET, UK. https://doi.org/10.5285/0fdd7082-5fbc-4923-bl66-d7adcb9cl70f. Direct link https://doi.org/10.5285/0fdd7082-5fbc-4923-bl66-d7adcb9cl70f or https://doi.org/b7d4.

Author Contributions: LES and SJW jointly conceived the study and wrote the paper; LES performed the research and analysed the data; NM contributed to the research.

*Corresponding author; e-mail: s.woodin@abdn.ac.uk

\section{INTRODUCTION}

It is well established that metabolic processes in Arctic plants and soils are often nutrient limited, by nitrogen $(\mathrm{N})$ or by $\mathrm{N}$ and phosphorus (P) (for example, Shaver and Chapin 1995). Potential increases in the availability of nutrients, whether through anthropogenic inputs or soil warming, may therefore result in increased vegetation productivity (Shaver and Chapin 1995) and/or increased microbial activity and soil organic matter (SOM) decomposition (Hartley and others 2010). The balance between plant growth and SOM decay largely determines net $\mathrm{C}$ storage, which in the Arctic has global significance. Permafrost soils (in- 
cluding those in sub-Arctic regions) are estimated to account for approximately $1300 \mathrm{Pg}$ carbon, around $40 \%$ of global soil C (Schuur and others 2015). Although Arctic ecosystems have been a C sink for the past 10,000 years, a recent metaanalysis suggests that since the 2000s they may have become a net $\mathrm{C}$ source (Belshe and others 2013). It is imperative therefore that we understand how the processes governing ecosystem C balance respond to nutrient availability, as these processes will be critical in determining the global impact of rapid Arctic climate change.

Nitrogen is likely to become more available in Arctic ecosystems, primarily as a result of increases in temperature and soil mineralisation (Jiang and others 2016), but also through potential increases in atmospheric $\mathrm{N}$ deposition resulting from projected increases in Arctic precipitation (Kühnel and others 2011). Also, as sea ice decreases, potential expansion of Arctic shipping would produce additional $\mathrm{NO}_{x}$ emissions and thus may increase $\mathrm{N}$ deposition (Winther and others 2014), as would any resultant increase in resource exploitation within the Arctic (Harsem and others 2011). The effect of this on $\mathrm{C}$ stocks may depend on $\mathrm{P}$ availability; however, the response of the $\mathrm{P}$ cycle to environmental change has largely been overlooked because of a research focus on $\mathrm{N}$ limitation (Wieder and others 2015). However, on the basis of multiple element limitation modelling of vegetation and soil on the North Slope of Alaska, Jiang and others (2016) predict that $\mathrm{P}$ availability will have a stronger influence than $\mathrm{N}$ on the future $\mathrm{C}$ stock of the ecosystem.

Increased $\mathrm{N}$ availability is generally predicted to result in an increase in ecosystem $C$ sequestration, particularly in forests (for example, de Vries and others 2009), but this does not always hold true for low-nutrient ecosystems, more comparable to tundra. For example, $\mathrm{N}$ addition to bogs may result in net decrease in $\mathrm{C}$ sequestration through changes to litter production and soil respiration (Bragazza and others 2006, 2012). The response of Arctic ecosystem $\mathrm{C}$ sequestration to $\mathrm{N}$, and particularly to the relative availability of $\mathrm{N}$ and $\mathrm{P}$, is little known. In moist acidic Alaskan tundra, total C stock was reduced by combined $\mathrm{N}$ and $\mathrm{P}$ fertilisation (Mack and others 2004). In contrast, NP fertilisation had no effect on ecosystem C stock in tall deciduous shrub tundra in the same region (DeMarco and others 2014). However, to our knowledge there are no studies of the effects of $\mathrm{N}$ alone, or in relation to $\mathrm{P}$ availability, on total $\mathrm{C}$ stocks in Arctic ecosystems.

Studies of the effect of $\mathrm{N}$ enrichment on ecosystem $\mathrm{C}$ inputs and outputs may inform predictions of effects on net $C$ sequestration, but they demonstrate considerable variation in response. For example, aboveground production in low Arctic mesic tundra (Zamin and others 2014) and aboveground biomass in Alaskan dry heath (Gough and others 2002) have been shown to decrease in response to $\mathrm{N}$ addition. There was no response of aboveground biomass to $\mathrm{N}$ alone in moist nonacidic and acidic tundra in Alaska (Gough and Hobbie 2003; Shaver and others 1998), whilst in a dwarf shrub heath in Greenland aboveground biomass (measured as NDVI) was increased by $\mathrm{N}$ addition (Arens and others 2008). However, in all these studies, the combination of $\mathrm{N}$ and $\mathrm{P}$ fertilisation had a large, significant, and mostly interactive, positive effect on aboveground production or biomass; a response also seen in Arctic NP fertilisation experiments in which the individual effects of $\mathrm{N}$ and $\mathrm{P}$ were not investigated (for example, Mack and others 2004; DeMarco and others 2014). Despite positive biomass responses, there was no change in net $\mathrm{CO}_{2}$ flux in response to $\mathrm{N}$ alone in the Alaskan moist tundra (Shaver and others 1998) and an increase in net $\mathrm{CO}_{2}$ efflux in the Greenland heath (Arens and others 2008). In both cases, however, the addition of both $\mathrm{N}$ and $\mathrm{P}$ caused significant interactive increase in the $\mathrm{CO}_{2}$ sink strength of the system.

Soil respiration in the Greenland heath did not respond to $\mathrm{N}$ alone, but was greatly increased by the interactive effects of $\mathrm{N}$ and $\mathrm{P}$ (Arens and others 2008), and similarly in a laboratory study, subArctic soil organic matter mineralisation was not affected by $\mathrm{N}$ alone, but increased in response to $\mathrm{N}$ plus P (Hartley and others 2010). Consistent with this, the reduction in total $\mathrm{C}$ stock of moist acidic tundra in response to NP was caused by loss of older C from deep soil (Mack and others 2004; Nowinski and others 2008). Laboratory studies on tundra soils do not always follow the same pattern, however. For example, the effect of $\mathrm{N}$ and $\mathrm{P}$ addition on $\mathrm{C}$ loss during long-term soil incubations was small and varied with vegetation type (Shaver and others 2006). Laboratory studies have also shown that $\mathrm{N}$ alone can have a short-term stimulatory effect on decomposition processes (Sistla and others 2012), though these effects appear to decrease over time (Lavoie and others 2011).

This study investigates the long-term (20 years) legacy effects of short-term nutrient enrichment, which has created different relative availability of $\mathrm{N}$ and $\mathrm{P}$, on total $\mathrm{C}$ stocks in high Arctic Cassiope tetragona dominated tundra heath. This system is $\mathrm{N}$ and P co-limited (Gordon and others 2001; Street and others 2015), and thus, we predict that the 
response of vegetation and organic soil C stocks to $\mathrm{N}$ will be dependent on $\mathrm{P}$ availability. The vegetation at our study site is moss dominated $(70 \%$ moss cover, Gordon and others 2001). Moss is very important in Arctic ecosystem C and nutrient cycles as it contributes a significant proportion of total productivity (Street and others 2012a, b), sequesters nutrients, and produces very recalcitrant litter which decomposes slowly (for example, Lindo and Gonzalez 2010; Turetsky and others 2012). The moss layer influences soil temperature and moisture beneath it, with the result that mineralisation is decreased beneath a thick moss layer (Gornall and others 2007). Moss is also very sensitive to nutrient enrichment and at our tundra study site has shown a dramatic increase in cover in response to the combination of $\mathrm{N}$ and $\mathrm{P}$ fertilisation (Street and others 2015).

Based on the evidence from fertilisation studies summarised above, and the character of the vegetation at our study site, we hypothesise that:

(1) Nitrogen enrichment of high Arctic dwarf shrub tundra heath which is co-limited by $\mathrm{P}$ will result in no change to total $\mathrm{C}$ stocks in vegetation and organic soil.

(2) Nitrogen enrichment of high Arctic dwarf shrub tundra heath in which $\mathrm{P}$ limitation is alleviated will result in an increase in aboveground biomass which, given the dominance of moss, may result in an increase in total C stocks in vegetation and organic soil.

(3) The response of the moss layer to $\mathrm{N}$ and $\mathrm{P}$ will have a controlling influence on the total $\mathrm{C}$ stocks in both vegetation and organic soil.

\section{Materials ANd Methods}

\section{Field Experiment}

Experimental fertilisation of tundra heath $1.5 \mathrm{~km}$ SE of Ny-Ålesund, Svalbard $\left(78^{\circ} 56^{\prime} \mathrm{N}, 11^{\circ} 58^{\prime} \mathrm{E}\right)$ was undertaken during 1991-1993 (Gordon and others 2001). The vegetation at the site is classified as prostrate dwarf shrub tundra according to the Circumpolar Arctic Vegetation Map (Walker and others 2005) and has previously been shown to be co-limited by N and P (Gordon and others 2001; Street and others 2015). A factorial combination of nitrogen $\left(0\right.$ and $5 \mathrm{~g} \mathrm{~N} \mathrm{~m}^{-2} \mathrm{y}^{-1}$ as $\mathrm{NH}_{4} \mathrm{NO}_{3}$ solution) and phosphorus (0 and $0.5 \mathrm{~g} \mathrm{P} \mathrm{m}^{-2} \mathrm{y}^{-1}$ as $\mathrm{KH}_{2} \mathrm{PO}_{4}$ solution) were applied to $1.5 \times 1.5 \mathrm{~m}$ plots ( 5 replicates per treatment) within an area of vegetation dominated by Cassiope tetragona (L.) D. Don (average cover of $11 \%$ ) with continuous bryophyte cover. Nutrients were watered onto the plots in five applications each growing season (midJune to mid-August), each equivalent to $2 \mathrm{~mm}$ precipitation. Three additional treatment applications were made on the same plots in 2000 (as part of a study investigating the degree of ecosystem $\mathrm{N}$ saturation in response to treatment) such that the total experimental $\mathrm{N}$ input was $18 \mathrm{~g} \mathrm{~m}^{-2}$ and the total experimental $\mathrm{P}$ input was $1.8 \mathrm{~g} \mathrm{~m}^{-2}$. Detailed information on the effects of treatment on vegetation species composition, ecosystem nitrogen saturation and plant nutrient status is presented in Street and others (2015).

\section{Plant and Soil Sampling and Analysis}

We sampled the fertilisation experiment in July 2011,20 years after its initiation and 18 years after the main treatment period. Two plant/soil turves $(10 \times 5 \mathrm{~cm}$, to below the organic horizon) were collected from each plot; the location of each turf was randomly selected to capture small-scale within-plot variability. The depth of the moss (green and brown intact moss tissue) and soil organic layers were measured on each side of each turf in the field. The interface between intact mosses (green and brown parts) and the soil organic horizon was well defined. Turfs were stored at $4^{\circ} \mathrm{C}$ and within 1 week were sorted into aboveground vascular plant biomass, green moss, litter (comprising the lower, brown part of the moss and a small amount of vascular plant litter), organic soil and mineral soil. Each fraction was immediately dried $\left(70^{\circ} \mathrm{C}, 48 \mathrm{~h}\right)$ and weighed. One 4.2 -cm-diameter soil core was also taken from each plot (after removing the moss layer), and the soil organic horizon and top $0-3 \mathrm{~cm}$ of the mineral horizon were separated and used to calculate bulk density. Mass and volume of stones where they occurred (in c. $20 \%$ of samples) were accounted for in bulk density measurements. Soil and litter samples, which were too large to mill in their entirety, were coarsely ground using a laboratory blender to ensure thorough mixing before being subsampled for fine milling. All material was steel ball milled (F.Kurt Retsch GMbH and Co. KG, MM200, Germany) prior to $\mathrm{CN}$ analysis (CarloErba NA 1500 Series 2, USA) and total P determination by hydrogen peroxide/sulphuric acid digestion and Flow Injection Analysis (Technicon autoanalyser, Sterilin Instruments, Herts, UK). Total carbon stocks are reported for the vegetation and soil organic layers only. The depth of the mineral soil layer above frost-shattered parent material was extremely variable (range 2.8- 
$10.0 \mathrm{~cm})$, making treatment effects on total carbon stocks in mineral soils difficult to detect with the available replication $(n=5)$. We therefore only sampled the top $3 \mathrm{~cm}$ of the mineral horizon to quantify potential changes in soil carbon content and bulk density in the surface mineral layers.

Temperature was recorded at the moss-soil interface (that is, at the top of the organic soil, but beneath the moss layer, the depth of which was variable) at a randomly located position within each of the control, $\mathrm{N}$ and NP treatment plots during 8-31st July 2011. Measurements were taken every $0.5 \mathrm{~h}$ using ibutton data loggers (DS1922L-F5 thermochrons (high capacity) - 40 to $+85^{\circ} \mathrm{C}$, Homechip). Normalised Difference Vegetation Index (NDVI) was recorded as an indicator of productivity (Street and others 2012a). NDVI measurements were taken with a skye portable field sensor (Skye Instruments Ltd, Powys, UK) during 18-21st July 2011. Nine readings were taken per plot in a regular grid, with the sensor at a height of $1 \mathrm{~m}$ above each plot.

\section{Soil Decomposition Processes}

We compared the instantaneous temperature sensitivity of soil respiration in the laboratory, as a potential indicator of soil organic matter recalcitrance. Kinetic theory suggests that respiration of more complex, low-quality soil organic matter should be more responsive to temperature (Conant and others 2011; Dungait and others 2012). Respiration rates were measured ex situ for each plot $(n=5)$ for the control, $\mathrm{N}$ and NP treatments, on soil from the organic layer of a sample of known area (c. $4.5 \times 4.5 \mathrm{~cm}$ ) removed from one of the replicate plant/soil turves from each plot prior to the splitting of soil layers for drying and chemical analysis (above). Soil was pre-incubated at $4{ }^{\circ} \mathrm{C}$ for 1 month prior to respiration analysis. The soil was lightly homogenised by hand, coarse roots were removed for a standardised 15 min per sample and each sample was split into subsamples for determination of water holding capacity (WHC), C content (analysis as above) and respiration. For respiration measurement, c. $10 \mathrm{~cm}^{3}$ (20-30 g fresh weight) of soil was placed in a custom-made $50-\mathrm{ml}$ universal tube "chamber", soil water content was standardised to $60 \%$ of WHC and the sample equilibrated at $4^{\circ} \mathrm{C}$ for 3 days. Soil respiration was measured sequentially at 5.5, 10.5, 20.5, 25.5 and $30.5^{\circ} \mathrm{C}$ with each sample being incubated at each temperature for $1 \mathrm{~h}$ before measurement in order to measure the instantaneous response of soil respiration to temperature $(\mathrm{l} \mathrm{h}$ is not long enough for adaptive responses at the community level (Hartley and others 2008). The chamber was connected to an IRGA (LI-8100, Licor Biosciences, Inc.), $\mathrm{CO}_{2}$ accumulation was recorded over 1 min and soil efflux was calculated from the increase in $\mathrm{CO}_{2}$ concentration and expressed as $\mathrm{mg} \mathrm{CO}_{2}-\mathrm{C} \mathrm{g}^{-1}$ soil $\mathrm{C} \mathrm{h}^{-1}$.

An additional set of soil samples were collected in August 2015 and stored at $4{ }^{\circ} \mathrm{C}$ for one week prior to cellobiohydrolase (EC 3.2.1.91) ( $\mathrm{CBH}$ ) assay being undertaken as in Currey and others (2010). Sample suspensions were prepared by adding $0.1 \mathrm{~g}$ of field moist soil from the organic layer $(0-2 \mathrm{~cm})$ to $12.5 \mathrm{ml}$ of $50 \mathrm{mM}$ acetate buffer $\mathrm{pH} 5.5$, and vortexing on an orbital shaker for 1 min. Triplicate $200-\mu \mathrm{l}$ aliquots of the suspension were distributed to a 96-well plate and $50 \mu \mathrm{l}$ of $200 \mu \mathrm{M} 4$-MUB- $\beta$ $\mathrm{D}$-cellobiose was added to initiate the assay. Samples were incubated in the dark at $10^{\circ} \mathrm{C}$ for $1 \mathrm{~h}$. Assays were terminated by addition of $10 \mu \mathrm{l} \mathrm{M}$ $\mathrm{NaOH}$. Fluorescence was measured with a microplate fluorometer with 360-nm excitation and 460$\mathrm{nm}$ emission filters (CytoFluor Series 400, PerSeptive Biosystems). Blanks ( $50 \mu \mathrm{l}$ acetate buffer and $200 \mu \mathrm{l}$ sample suspension), negative controls $(50 \mu \mathrm{l}$ substrate suspension and $200 \mu \mathrm{l}$ acetate buffer), quench standards $(50 \mu \mathrm{l}$ standard $(0.1 \mu \mathrm{M}$ 4methylumbelliferone (MUB)) and $200 \mu$ l sample suspension) and reference standards (50 $\mu \mathrm{l}$ MUB $(0-0.1 \mu \mathrm{M})$ plus $200 \mu \mathrm{l}$ acetate buffer) were also run. Samples were blank- and negative controlcorrected. Corrected sample values were multiplied by the quench factor (reference standard/quench standard) to correct for soil masking fluorescence. Soil dry weight was determined using a fresh weight-to-dry weight ratio. Activities were expressed in units of $\mu \mathrm{mol}$ MUB $\mathrm{g}^{-1} \mathrm{DW} \mathrm{h}^{-1}$.

\section{Statistics}

We examined the fixed effects of $\mathrm{N}$ and $\mathrm{P}$ treatment on moss and organic soil layer depths, carbon and nitrogen stocks and concentrations in vegetation and soil pools, moss $\mathrm{C}$-to- $\mathrm{N}$ ratio and $\mathrm{CBH}$ activity using two-way ANOVA with Tukey's HSD post hoc tests. Data were transformed where necessary to meet assumptions of normality and homogeneity of variance in model residuals ( $\log$ transformation for horizon depths, C stocks (vascular, organic soil and total), $\mathrm{N}$ stocks (moss and total) and square root transformation for CBH activity).

To further explain the variability in organic and moss layer depths, we fitted multivariate models using the "leaps" package for $\mathrm{R}$ (version 3.1.2) which included the fixed effects of treatment 
$(\mathrm{N} \times \mathrm{P})$, the $\mathrm{N}$-to-P and $\mathrm{C}$-to- $\mathrm{N}$ ratios of moss, litter and organic soils, NDVI and moss layer depth (for the organic soil model only) as explanatory variables. This approach involves an exhaustive search of all possible regression models which avoids the pitfalls of stepwise regression, that is, that (1) the "best" model can depend on the starting point and the order in which variables are added or removed and (2) there might be several "almost as good" models which are not considered. Model selection is based on Mallow's Cp statistic (an information criterion equivalent to AIC).

To compare the temperature sensitivity of respiration between treatments, we fitted a standard temperature sensitivity model (Reichstein and others 2005) (equation 1) using general nonlinear least-squares fitting procedures in the "nlme" library for $R$ including a fixed effect of treatment on the $Q_{10}$ value (version 3.1.2).

$$
R_{\text {soil }}=R_{\text {ref }} \times Q_{10}^{\left(T_{\text {soil }}-T_{\text {ref }}\right) / 10}
$$

where $R_{\text {soil }}$ is the instantaneous soil $\mathrm{CO}_{2}$ efflux $\left(\mathrm{mg} \mathrm{C} \mathrm{g}^{-1} \mathrm{~h}^{-1}\right), T_{\text {soil }}$ is incubation temperature, $R_{\text {ref }}$ is the reference flux $\left(\mathrm{mg} \mathrm{C} \mathrm{g}^{-1} \mathrm{~h}^{-1}\right)$ at $T_{\text {ref }}$ of $15^{\circ} \mathrm{C}$ (the $T_{\text {ref }}$ value used by Reichstein and others (2005)) and $Q_{10}$ the parameter that determines the temperature response of the soil $\mathrm{CO}_{2}$ flux.

\section{RESUltS}

\section{Nutrient Effects on the Tundra Heath Ecosystem}

We observed altered ecosystem structure in response to added nutrients two decades after treatment. Treatment response was driven by significant interactive effects of $\mathrm{N} \times \mathrm{P}($ ANOVA, $p<0.01)$ on both moss and organic soil depths (Figure 1A). The depth of the moss layer was increased by about $70 \%$ by $\mathrm{N}$ plus $\mathrm{P}$ addition (relative to control) (Tukey HSD $p=0.09$ ), but in contrast, $\mathrm{N}$ alone tended to reduce moss layer depth by about 50\% relative to the control (though this effect was not significant, Tukey HSD, $p=0.12$ ) (Figure 1A). Soil organic layer depth was similarly increased by about $50 \%$ by N plus P (Tukey HSD, $p=0.09$ ) and was reduced by about $40 \%$ by addition of $\mathrm{N}$ alone (Tukey HSD, $p<0.01$ ) (Figure 1A). There was no effect of the $\mathrm{P}$ alone treatment on either moss (Tukey HSD $p=0.99$ ) or organic soil depths (Tukey HSD $p=0.35$ ) relative to controls.

The changes in the depth of the moss and soil layers were the primary drivers of $\mathrm{C}$ stock responses to nutrient treatments, with $99 \%$ of the variation in total organic carbon stocks across treatments being explained by the combined depth of the two layers (Figure 1B). Again a highly significant interaction effect between $\mathrm{N}$ and $\mathrm{P}$ drove the treatment responses (ANOVA, $p<0.001$ ). As a result, increased availability of both $\mathrm{N}$ and $\mathrm{P}$ resulted in a $56 \%$ increase in organic C stocks (Tukey HSD, $p<0.05)$, whereas application of $\mathrm{N}$ alone resulted in a $44 \%$ loss of organic C compared to control (Tukey HSD, $p<0.01$ ) (Figure 2A). The combined $\mathrm{C}$ pools of the litter and soil organic layer, where decomposition processes occur, similarly exhibited a $41 \%$ decrease in N-only plots, relative to controls (Tukey HSD, $p<0.05$ ).

There were no significant treatment effects on $\mathrm{C}$ concentration ( $\%$ dry mass) of aboveground vascular plant and green moss tissues, but $\mathrm{N}$ plus $\mathrm{P}$ treatment resulted in a $10 \%$ increase in the $\mathrm{C}$ concentration of litter (Tukey HSD, $p<0.05$ ) and a non-significant increase in the $\mathrm{C}$ concentration of organic soil (Tukey HSD, $p<0.1$ ) relative to controls (Figure S1A). There was no change in \% C of the mineral soil (Figure S2).

The effects of treatment on N stocks (Figure 2B) closely mirrored those on $\mathrm{C}$ stocks. A strongly significant $\mathrm{N} \times \mathrm{P}$ interaction effect on $\mathrm{N}$ stocks $(\mathrm{AN}$ OVA, $p<0.01)$ reflects the fact that the $\mathrm{N}$ alone treatment resulted in a $37 \%$ reduction in total $\mathrm{N}$ stock compared to control (Tukey HSD, $p<0.1$ ) (that is, equivalent to loss of all the added $\mathrm{N}$ plus $37 \%$ of ecosystem $\mathrm{N}$ ), whilst $\mathrm{N}$ plus $\mathrm{P}$ addition resulted in a $29 \%$ increase in total $\mathrm{N}$ stock (equivalent to retention of $72 \%$ of the added $\mathrm{N}$ over 20 years), although this was not statistically significant.

Nitrogen concentrations (\% dry mass) in plants, litter and soil were not significantly affected by treatment, other than a decrease in $\% \mathrm{~N}$ in vascular plant leaves in response to $\mathrm{P}$ alone (Tukey HSD, $p<0.05$ ), and a weakly significant decrease in moss \% $\mathrm{N}$ in the $\mathrm{N}$ plus $\mathrm{P}$ treatment compared to $\mathrm{P}$ only (Tukey HSD, $p<0.1$ ) (Figure S1B).

In the green moss, total $\mathrm{N}$ pool increased 2.4-fold in response to $\mathrm{N}$ plus $\mathrm{P}$ addition (Figure 2B), whereas the total $\mathrm{C}$ pool increased 3.4-fold (Figure $2 \mathrm{~A}$ ). This led to a significant increase in C-to-N ratio of the moss layer in the $\mathrm{N}$ plus $\mathrm{P}$ treatment compared to controls (Tukey HSD, $p<0.05$ ) (Figure 3).

The change in depth of the moss and soil organic layers also influenced the soil physico-chemical environment. Summer soil temperatures in our experiment were increased (compared to control) beneath the thinner moss layer resulting from $\mathrm{N}$ treatment and decreased under the thicker moss layer resulting from $\mathrm{N}$ plus $\mathrm{P}$ (Figure 4). The total 

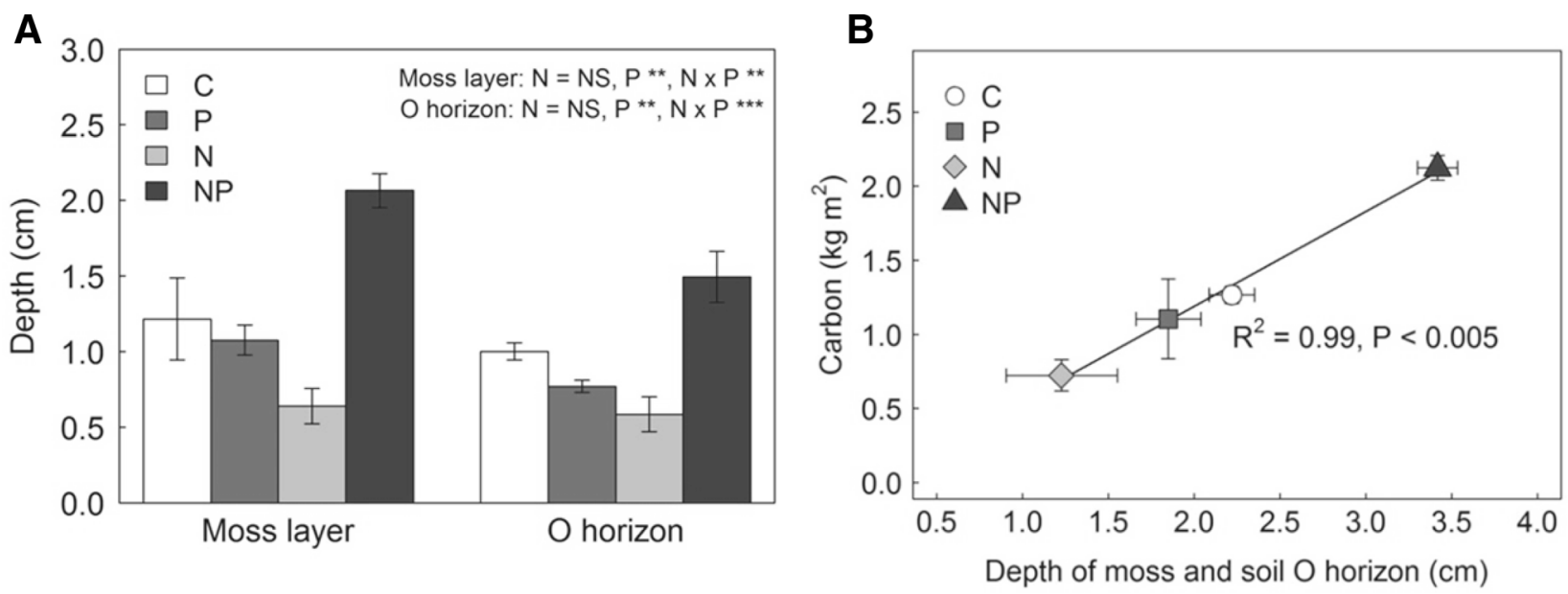

Figure 1. Nutrient effects on moss layer (including the green and brown intact moss) and soil organic horizon depths and their influence on ecosystem carbon stocks. A Treatment effects on moss layer and soil organic horizon depth. Significance of the two main factors $(\mathrm{N}, \mathrm{P})$ and their interaction $(\mathrm{N} \times \mathrm{P})$ in two-way ANOVA is indicated by: NS non-significant, ${ }^{*} p \leq 0.05,{ }^{* *} p \leq 0.01,{ }^{* * *} p \leq 0.001$. ANOVA results are provided in Table S1. B Relationship between carbon stock and the total depth of moss and organic soil. $C$ control; $P$ phosphorus; $N$ nitrogen; $N P$ nitrogen plus phosphorus. Values are mean \pm s.e.m $(n=5)$.

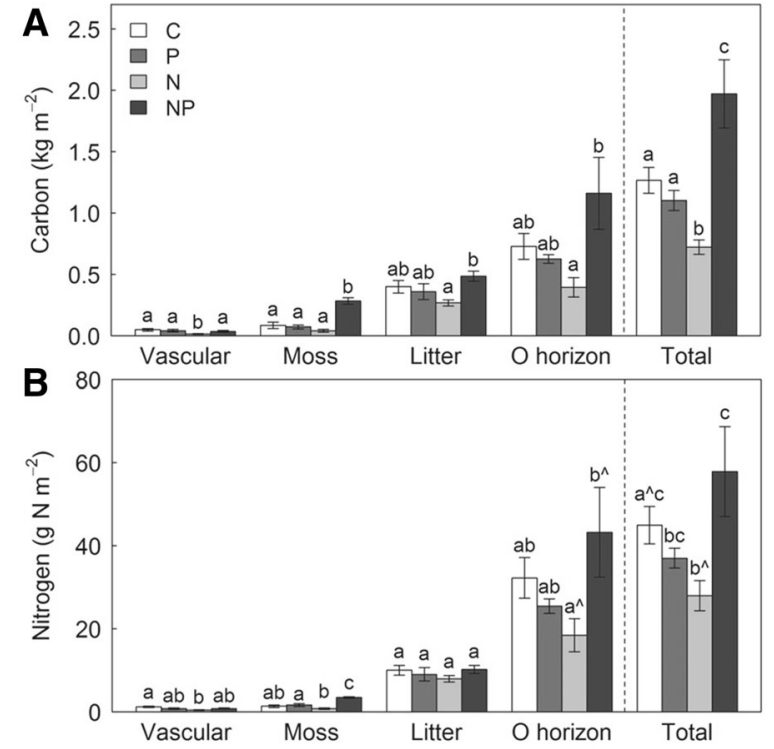

Figure 2. Nutrient treatment effects on carbon and nitrogen stocks. A carbon stocks and $\mathbf{B}$ nitrogen stocks in vascular plants, green moss, litter (brown moss and vascular plant litter), soil $\mathrm{O}$ horizon and total organic pools. $C$ control; $P$ phosphorus; $N$ nitrogen; $N P$ nitrogen plus phosphorus. Different letters indicate significant differences within a group (ANOVA, Tukey HSD) at $p<0.05$; if both letters are followed by ${ }^{\wedge}$, significance is at $p<0.1$. ANOVA results are provided in Table S2. Values are mean \pm s.e.m $(n=5)$.

depth of moss and organic soil was also positively related to bulk density in the top layer of mineral soil $\left(R^{2}=0.93\right.$; Figure S3).

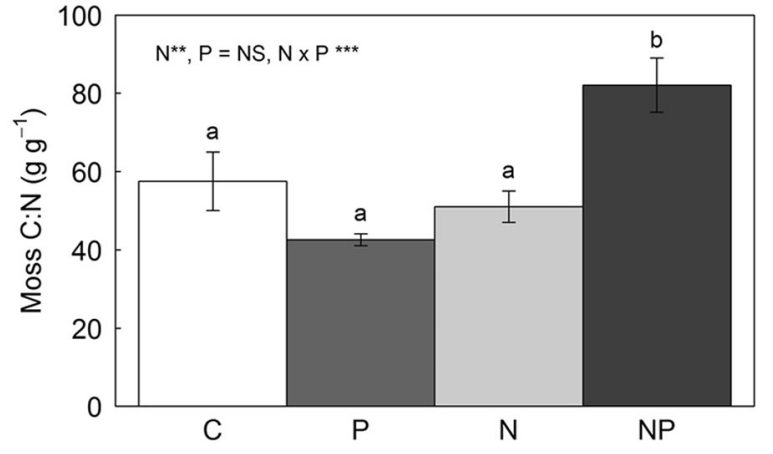

Figure 3. Nutrient treatment effects on C-to-N ratio $\left(\mathrm{g} \mathrm{g}^{-1}\right)$ of the green moss. $C$ control; $P$ phosphorus; $N$ nitrogen; $N P$ nitrogen plus phosphorus. Significance of the two main factors $(\mathrm{N}, \mathrm{P})$ and their interaction $(\mathrm{N} \times \mathrm{P})$ in two-way ANOVA are indicated by: NS non-significant, ${ }^{* *} p \leq 0.01,{ }^{* * *} p \leq 0.001$. Different letters above bars indicate significant differences (Tukey HSD at $p<0.05$ ). Values are mean \pm s.e.m $(n=5)$.

\section{How do Nutrients Influence Moss and Organic Soil Depths?}

The responses of tundra $\mathrm{C}$ stocks to nutrient availability observed in our system clearly depend on the mechanisms by which $\mathrm{N}$ and $\mathrm{P}$ influence the depths of the moss and organic soil layers (Figure 1B). Moss depth is best explained by a model including NDVI (which was significantly positively related to vegetation gross primary productivity; Figure $\mathrm{S} 4$ ), the $\mathrm{C}$-to- $\mathrm{N}$ ratio of the live, green moss and an effect of $\mathrm{N}$ treatment (Figure S5A, Table S3). 


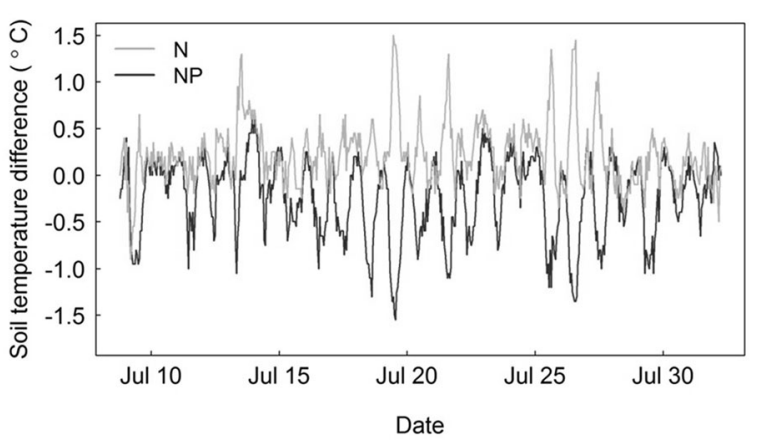

Figure 4. Difference in soil temperature (directly beneath the moss layer) between treated ( $\mathrm{N}$ and $\mathrm{NP}$ ) and control plots during July 2011 . Average soil temperature in controls plots over the measurement period was $9^{\circ} \mathrm{C}$. $(n=5)$.

The retention of C:N and NDVI as covariates in the model, even after accounting for the fixed effect of $\mathrm{N}$ treatment, indicates that moss depth, tissue C:N and NDVI are not all responding independently to treatment in a similar way (but otherwise unrelated). If this was the case, the model selection procedure would only retain the treatment effect as an explanator in the model, and the covariates would not provide any additional information. NDVI has a strong positive association with moss depth and was not affected by addition of $\mathrm{N}$ alone but increased in response to $\mathrm{N}$ where $\mathrm{P}$ was also added (Figure 5A). The C-to-N ratio of the live moss is also very strongly associated with moss depth and increased in response to $\mathrm{N}$ plus $\mathrm{P}$ application (Figure 5B). Beyond these influences, N treatment itself had a negative impact on moss depth (Table S2).

Organic layer depth is best explained by a model including treatment effects $(\mathrm{N}$ and NxP interaction), NDVI and the $\mathrm{N}: \mathrm{P}$ of the live moss (Figure S5B, Table S3); thus, the depth of organic soil is clearly related to the properties of the moss layer. Increase in productivity (NDVI) in response to $\mathrm{N}$ plus $\mathrm{P}$ addition (Figure 5A) reflects an increase in moss biomass (illustrated by moss C stock, Figure 2A) and cover (Street and others 2015). This increase in productivity is related to soil organic layer depth (Figure 5C), presumably through increasing $\mathrm{C}$ inputs. Organic layer depth was also weakly, but significantly, negatively related to moss tissue N:P (Figure 5D). There was, in addition, a direct negative effect of $\mathrm{N}$ treatment on soil organic layer depth, whilst the $\mathrm{N} \times \mathrm{P}$ interaction caused an increase in depth (Table S3).

Activity of cellobiohydrolase in the organic soil was influenced by treatment, with a clear, negative effect of $\mathrm{P}$ addition on activity $(p<0.01)$, and a weakly significant interaction effect between $\mathrm{N}$ and $\mathrm{P}(p=0.07)$. The interaction term suggests that the response of $\mathrm{CBH}$ activity to $\mathrm{N}$ is dependent on $\mathrm{P}$ because $\mathrm{CBH}$ activity was significantly higher in $\mathrm{N}$ only-treated plots, relative to $\mathrm{N}$ plus $\mathrm{P}$-treated plots (Tukey HSD, $p<0.05$ ) and P-treated plots (Tukey HSD, $p=0.05$ ) (Figure 6A). Nutrient addition also affected the response of soil respiration to temperature, which was enhanced in soil from $\mathrm{N}$ plus $\mathrm{P}$ plots (Figure 6B).

\section{Discussion}

This study demonstrates that short-term $\mathrm{N}$ enrichment of high Arctic dwarf shrub tundra has a longterm influence on ecosystem $\mathrm{C}$ stocks, with the outcome depending on $\mathrm{P}$ availability.

\section{The Impact of $\mathrm{N}$ Enrichment when $\mathrm{P}$ is Co-Limiting}

Our expectation was that $\mathrm{N}$ enrichment in an ecosystem previously demonstrated to be co-limited by N and P (Gordon and others 2001; Street and others 2015) would result in no net change in ecosystem C stocks-because both plant productivity and microbial decomposition would be unable to respond to $\mathrm{N}$ without an additional supply of P. Our data show, however, that addition of $\mathrm{N}$ alone has resulted in thinner moss and soil organic layers and reduced ecosystem C stocks. Whilst we do not have continuous direct measures of respiration fluxes over the two decades of the experiment, we suggest that the loss of $\mathrm{C}$ has been driven primarily by an increase in decomposition rates in response to $\mathrm{N}$. (There was no clear impact of $\mathrm{N}$ alone on plant productivity.) Evidence that this is the case comes from (1) the significant loss of both $\mathrm{C}$ and $\mathrm{N}$ from the system following $\mathrm{N}$ treatment and (2) the increased activity of the cellulose degrading enzyme $\mathrm{CBH}$ in soil from $\mathrm{N}$-treated plots relative to P-treated plots, still evident more than two decades after $\mathrm{N}$ application. Although cellulolytic enzyme activity may not necessarily be directly correlated with bulk soil decomposition rates, increased mass loss of plant litter has been linked to increased CBH activity under mineral $\mathrm{N}$ addition (Sinsabaugh and others 2002).

Moss tissue decomposition rate is highly influenced by tissue C:N content (Lang and others 2009), and although we found no significant impact on $\mathrm{N}$ alone on moss $\mathrm{C}$-to- $\mathrm{N}$ ratios in $201 \mathrm{l}$, the negative effect of $\mathrm{N}$ on moss layer depth could reflect treatment impacts in earlier years post-treat- 

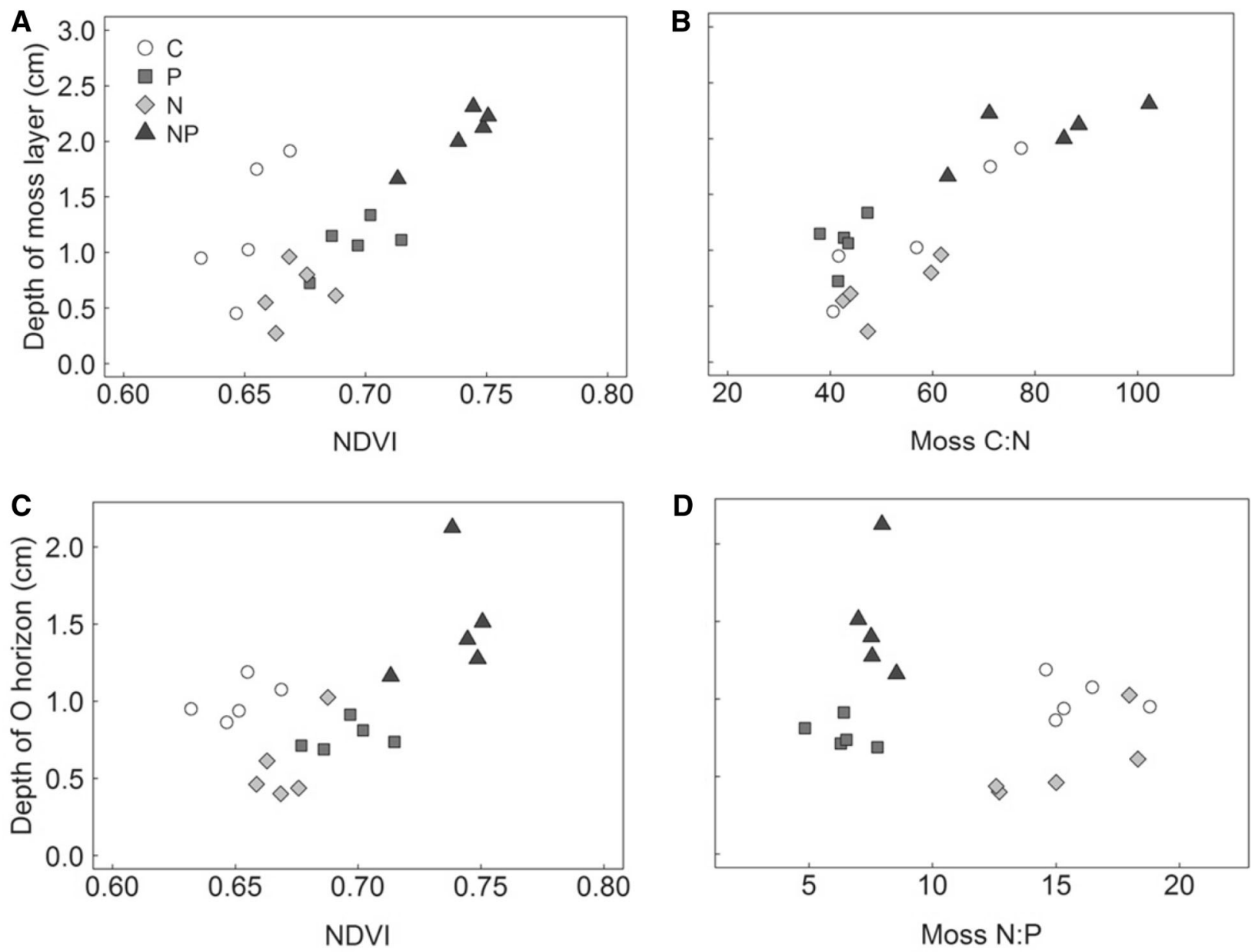

Figure 5. Factors explaining the variation in moss layer and soil organic horizon depths. Relationship between A moss layer depth and NDVI $(p=0.001)$, B moss layer depth and moss tissue C-to-N ratio $(p<0.001)$, C soil O horizon depth and NDVI $(p<0.05)$ and $\mathbf{D}$ soil O horizon depth and moss tissue N-to-P ratio $(p<0.05)$. $p$ values are from multiple leastsquares regression of the best-supported multiple-regression model, following model selection via exhaustive search (Figure S5, Table S3).

ment, when moss tissue $\mathrm{N}$ was elevated to a greater degree (Street and others 2015). This would have decreased tissue $\mathrm{C}$-to- $\mathrm{N}$ ratios and may have accelerated decomposition of the lower, decaying portion of the moss shoots, resulting in a thinner moss layer and less organic matter input to the soil.

We did not detect differences in absolute respiration rates per gram $\mathrm{C}$ in the laboratory at temperatures relevant to those found in the field. (Respiration rates were similar between treatments below c. $20^{\circ} \mathrm{C}$.) However, the laboratory measurements were taken under disturbed conditions, on soil which had been homogenised and pre-incubated, so would not be expected to reflect absolute rates in situ. We also found no difference in temperature sensitivity between control and $\mathrm{N}$ treatments which might suggest there is no current effect of $\mathrm{N}$ alone on overall SOM quality, even though $\mathrm{CBH}$ activity was elevated in $\mathrm{N}$ plots relative to the $\mathrm{N}$ plus $\mathrm{P}$ treatments. These results are not inconsistent-CBH activity during the later stages of decomposition has been shown to be more strongly related to microbial $\mathrm{C}: \mathrm{N}$ status than to substrate availability (Geisseler and Horwath 2009; Leitner and others 2012), and is known to respond positively to simulated $\mathrm{N}$ deposition (Henriksen and Breland 1999; Carreiro and others 2000). This might suggest that two decades after its application, the effect of $\mathrm{N}$ treatment on decomposition is operating more through direct effects on the composition or activity of the decomposer community than through changes in soil organic matter quality. Confirmation of this suggestion would, however, require further investigation. 
A

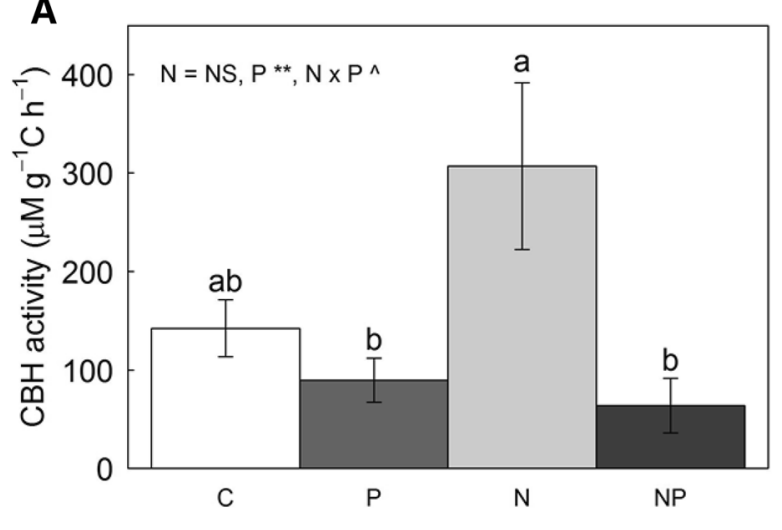

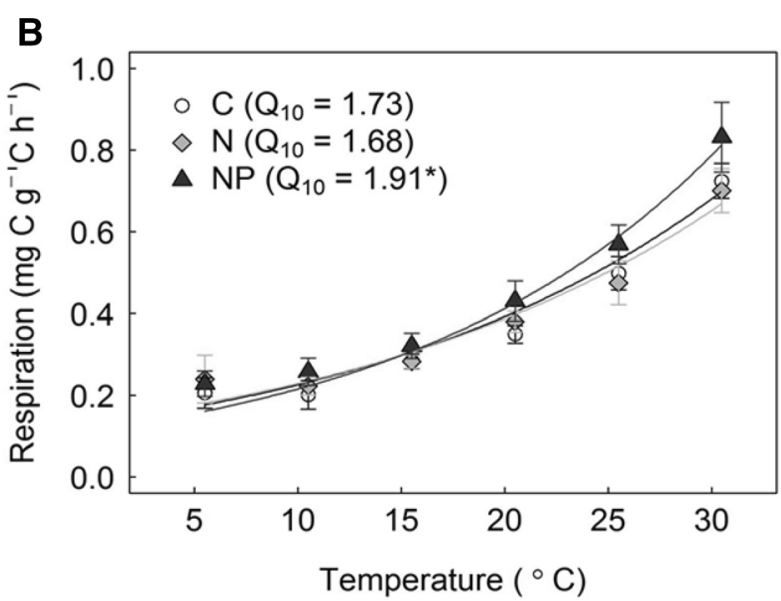

Figure 6. A Cellobiohydrolase activity $\left(\mu \mathrm{M} \mathrm{g}^{-1} \mathrm{C} \mathrm{h}^{-1}\right)$ in soils collected in August 2015. Significance of the two main factors $(\mathrm{N}, \mathrm{P})$ and their interaction $(\mathrm{N} \times \mathrm{P})$ in two-way ANOVA are indicated by: NS non-significant, $\wedge p<0.1$, ${ }^{* *} p \leq 0.01$. ANOVA results are provided in Table S4. Different letters above bars indicate significant differences (Tukey HSD at $p<0.05)$. Values are mean \pm s.e.m $(n=5)$. B Temperature response of ex situ soil respiration in soil from control (C) and treated $(\mathrm{N}, \mathrm{NP})$ plots. Symbols are measured values and represent mean \pm s.e.m $(n=5)$, and lines are the modelled temperature response. *Indicates a significant difference in fitted $Q_{10}$ value from the control value. Results of exponential temperature response model fitting are presented in Table S5.

\section{The Impact of N Enrichment when $\mathrm{P}$ is not Limiting}

As we expected, when $\mathrm{N}$ was added with $\mathrm{P}$, ecosystem $\mathrm{C}$ stocks increased. Addition of $\mathrm{N}$ with $\mathrm{P}$ has clearly enhanced moss productivity in the long term, as illustrated by increases in moss depth, moss cover (Street and others 2015) and NDVI. This has resulted in an overall dilution of $\mathrm{N}$ in moss biomass (Street and others 2015) and hence increased C:N which, in turn, may have slowed decomposition (Lang and others 2009). The net result is a thicker moss layer, formed of more recalcitrant tissue and thus holding greater $\mathrm{C}$ stocks. As moss litter forms a major organic $\mathrm{C}$ input to the soil, this in turn results in increased soil organic layer depth and C stock. Greater recalcitrance of this $\mathrm{C}$ stock is consistent with the observed enhancement of the soil respiration response to temperature (Conant and others 201 1; Dungait and others 2012) in soil from N plus P-treated plots. If lower-quality $\mathrm{C}$ has a slower turnover rate under natural conditions, we would expect greater organic $\mathrm{C}$ accumulation in situ which is exactly what we find in the $\mathrm{N}$ plus $\mathrm{P}$ plots. However, we cannot conclude that this is the only factor determining soil organic C turnover; the application of $\mathrm{N}$ plus $\mathrm{P}$ may have also affected microbial activity, for example by reducing microbial mining of organic matter for nutrients.

\section{The Role of the Moss Layer in Mediating Ecosystem Responses to N Deposition}

This study demonstrates the pivotal role of the moss layer in tundra ecosystem response to nutrients. Based on our observations in a high Arctic Cassiope heath, we propose a simple schematic model of the mechanisms by which $\mathrm{N}$ enrichment influences the thickness of the moss and soil organic layers, and hence their C stocks, through both productivity and decomposition, with the outcome depending on $\mathrm{P}$ availability (Figure 7). These mechanisms are mediated through the growth of moss and its tissue chemistry. Where $\mathrm{P}$ is limiting (or co-limiting as in our study system), $\mathrm{N}$ enrichment decreases moss C:N, enhancing decomposition and reducing the thickness of the moss and soil organic layers and hence their $C$ stocks (Figure 7A). Where $\mathrm{P}$ is not limiting, $\mathrm{N}$ enrichment increases moss growth which increases tissue $\mathrm{C}: \mathrm{N}$ and decreases decomposition rate, resulting in thicker layers of both moss and organic soil and greater $\mathrm{C}$ stocks (Figure $7 \mathrm{~B}$ ).

The depth of moss and organic soil not only dictates $\mathrm{C}$ stocks in the active layer by these direct mechanisms, but is also critical in determining soil thermal regimes (Yi and others 2007; Soudzilovskaia and others 2013) and protecting permafrost from thaw under warmer climatic conditions. The positive relationship between the depth of the moss plus organic soil and the bulk density of the top of the mineral soil in our 

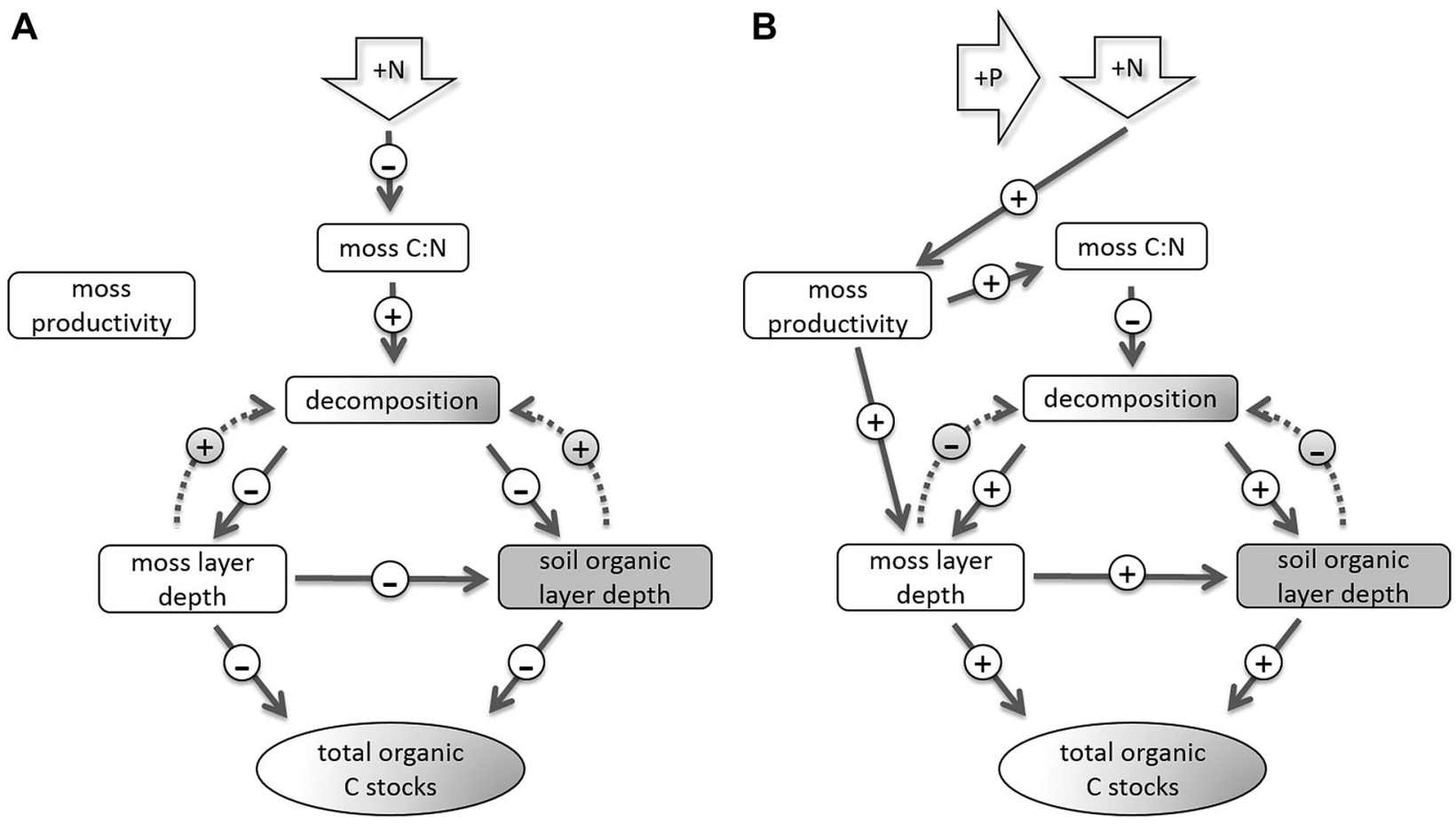

Figure 7. Conceptual model of the role of the moss layer in influencing $\mathrm{C}$ cycle responses to nutrients. Schematic of proposed mechanisms by which moss may mediate the influence of nitrogen enrichment on total carbon stocks in the moss layer and soil organic layer in scenarios in which A phosphorus is limiting (or co-limiting with N) and B phosphorus is not limiting. Solid arrows indicate direct effects; dashed arrows indicate indirect effect via influence on soil temperature. Arrows should be followed in sequence, for example, addition of $\mathrm{N}$ decreases moss C:N (-), which in turn increases decomposition $(+)$.

experiment suggests that these insulating layers reduce exposure to freeze-thaw cycles and cryoturbation. Moss depth has been shown to influence the rate of decomposition beneath it (Gornall and others 2007). The observed increase in summer soil temperatures beneath the thinner moss layer resulting from $\mathrm{N}$ treatment, and decrease in temperatures under the thicker moss layer resulting from $\mathrm{N}$ plus $\mathrm{P}$, may increase and decrease decomposition rates, respectively, thus amplifying the effect of $\mathrm{N}$ (Figure 7).

Whilst we treated the moss layer as a single carbon pool, we know that component moss species responded individualistically to treatment. For example, Polytichastrum alpinum and Philonotis spp. cover increased in response to $\mathrm{N}$, Hylocomium splendens, Aulacomnium turgidum and Ptilidium ciliare had increased in P-treated plots and Dicranum spp. responded to the combination of $\mathrm{N}$ and $\mathrm{P}$ (Street and others 2015). There were also nutrient effects on the vascular plant community, most notably a total loss of Cassiope cover (which was previously c. $20 \%$ ) in N and NP treatments following a winter icing event in 1994, which has not recovered (Street and others 2015). It is possible that loss of
Cassiope cover has had a direct impact on soil decomposition processes such as priming. However, given that Cassiope death occurred in both $\mathrm{N}$ and NP treatments and that aboveground vascular biomass contributes so little to total carbon stocks (Figure 2A), this loss of shrub cover has not contributed directly to the observed ecosystem $\mathrm{C}$ stock responses to N, with and without P. Given the lowshrub cover in this system (Cassiope cover was only $11 \%$ in control plots at the end of the experiment), it is also unlikely that shading has contributed to the moss response to treatment.

\section{Wider Implications}

The high Arctic system we studied had lower vegetation biomass and thinner organic soils than wetter, more productive graminoid and erect shrub tundra, and thus represents a much smaller carbon stock (Walker and others 2005; Campeau and others 2014; Hugelius and others 2014). Mosses, however, contribute significantly to vegetation biomass and productivity across the Arctic (Street and others 2012b; Turetsky and others 2012); thus, the mechanisms elucidated in our study, in which 
moss plays a pivotal role, could operate much more widely. The outcomes we observed were in response to $\mathrm{N}$ applied two decades previously; this clearly illustrates that nutrient retention in moss tissues (Street and others 2015) can influence the functioning of the plant/soil system over long periods. Moss is highly effective at intercepting and retaining nutrient inputs from above (Pouliot and others 2009) including atmospheric deposition and leaching from litter and plant canopies (Turetsky 2003), and so slows ecosystem nutrient turnover. Any reduction or loss of the moss layer may therefore accelerate the response of ecosystem nutrient turnover to temperature which, in turn, may further exacerbate the loss of ecosystem C stocks (Nowinski and others 2008; Koyama and others 2010).

There is general consensus that atmospheric $\mathrm{N}$ deposition increases ecosystem C sequestration (de Vries and others 2009; Liu and Greaver 2010). However, we demonstrate the opposite, the potential for loss of $\mathrm{C}$ in response to $\mathrm{N}$ deposition. In $\mathrm{N}$ and $\mathrm{P}$ co-limited dwarf shrub tundra, increased $\mathrm{N}$ availability resulted in a loss of organic $\mathrm{C}$ equating to $29 \mathrm{~kg} \mathrm{C}$ lost per $1 \mathrm{~kg} \mathrm{~N}$ added. We only observed an increase in $\mathrm{C}$ sequestration in response to $\mathrm{N}$ where $\mathrm{P}$ limitation was alleviated; $\mathrm{N}$ deposition then resulted in $39 \mathrm{~kg} \mathrm{C}$ gained per $1 \mathrm{~kg} \mathrm{~N}$ added. This is of the same magnitude, per unit $\mathrm{N}$, as the $\mathrm{C}$ gain generally attributed to $\mathrm{N}$ inputs in European forests and heathlands (most common range 20$40 \mathrm{~kg} \mathrm{C} \mathrm{kg}^{-1} \mathrm{~N}$ ) (de Vries and others 2009).

The potential role of $\mathrm{P}$ availability in determining long-term responses of ecosystem $\mathrm{C}$ sequestration to $\mathrm{N}$ inputs, whilst acknowledged (de Vries and Posch 2011; Zaehle and Dalmonech 2011; Peñuelas and others 2013), has only rarely been quantified (Franklin and others 2003), and has not previously been investigated in tundra. This study demonstrates that, in view of potential increases in $\mathrm{N}$ availability, prediction of the future trajectories of $\mathrm{C}$ storage in the Arctic requires a better understanding of how ecosystem $\mathrm{P}$ availability, distribution and dynamics might change in future in relation to increased soil temperatures, changing hydrology and altered periglacial processes including permafrost thaw. We clearly show that phosphorus plays a crucial role in determining the longterm fate and cycling of carbon in Arctic ecosystems.

\section{ACKNOWLEDGEMENTS}

This study was funded by NERC (NE/I016899/1) and facilitated by use of NERC facilities at Harland
Huset, Ny-Ålesund and the kind support of Nick Cox and colleagues. Nancy Burns assisted with field sampling and Brodie Shaw and Rob Mills assisted with laboratory analyses.

\section{Compliance with Ethical Standards}

Conflict of interest The authors declare that they have no conflict of interest.

\section{Open Access}

This article is distributed under the terms of the Creative Commons Attribution 4.0 International License (http://creativecommons.org/licenses/by/ 4.0/), which permits unrestricted use, distribution, and reproduction in any medium, provided you give appropriate credit to the original author(s) and the source, provide a link to the Creative Commons license, and indicate if changes were made.

\section{REFERENCES}

Arens SJT, Sullivan PF, Welker JM. 2008. Nonlinear responses to nitrogen and strong interactions with nitrogen and phosphorus additions drastically alter the structure and function of a high arctic ecosystem. Journal of Geophysical Research 113:G03S09. https://doi.org/10.1029/2007JG000508.

Belshe EF, Schuur EAG, Bolker BM. 2013. Tundra ecosystems observed to be $\mathrm{CO}_{2}$ sources due to differential amplification of the carbon cycle. Ecology Letters 16:1307-15.

Bragazza L, Buttler A, Habermacher J, Brancaleoni L, Gerdol R, Fritze H, Hanajik P, Laiho R, Johnson D. 2012. High nitrogen deposition alters the decomposition of bog plant litter and reduces carbon accumulation. Global Change Biology 18:1163-72.

Bragazza L, Freeman C, Jones T, Rydin H, Limpens J, Fenner N, Ellis T, Gerdol R, Hajek M, Hajek T, Lacumin P, Kutnar L, Tahvanainen T, Toberman H. 2006. Atmospheric nitrogen deposition promotes carbon loss from peat bogs. Proceedings of the National Academy of Sciences of the United States of America 103:19386-9.

Campeau AB, Lafleur PM, Humphreys ER. 2014. Landscapescale variability in soil organic carbon storage in the central Canadian Arctic. Canadian Journal of Soil Science 94:477-88.

Carreiro M, Sinsabaugh RL, Repert D, Parkhurst D. 2000. Microbial enzyme shifts explain litter decay responses to simulated nitrogen deposition. Ecology 81:2359-65.

Conant RT, Ryan MG, Ågren GI, Birge HE, Davidson EA, Eliasson PE, Evans SE, Frey SD, Giardina CP, Hopkins FM, Hyvönen R, Kirschbaum MUF, Lavallee JM, Leifeld J, Parton WJ, Megan Steinweg J, Wallenstein MD, Martin Wetterstedt JA, Bradford MA. 2011. Temperature and soil organic matter decomposition rates-synthesis of current knowledge and a way forward. Global Change Biology 17:3392-404.

Currey PM, Johnson D, Sheppard LJ, Leith ID, Toberman H, van der Wal R, Dawson LA, Artz RRE. 2010. Turnover of labile and recalcitrant soil carbon differ in response to nitrate and ammonium deposition in an ombrotrophic peatland. Global Change Biology 16:2307-21. 
DeMarco J, Mack MC, Bret-Harte MS, Burton M, Shaver GR. 2014. Long-term experimental warming and nutrient additions increase productivity in tall deciduous shrub tundra. Ecosphere 5(6):72. https://doi.org/10.1890/ES13-00281.1.

de Vries W, Posch M. 2011. Modelling the impact of nitrogen deposition, climate change and nutrient limitations on tree carbon sequestration in Europe for the period 1900-2050. Environmental Pollution 159:2289-99.

de Vries W, Solberg S, Dobbertin M, Sterba H, Laubhann D, van Oijen M, Evans C, Gundersen P, Kros J, Wamelink GWW, Reinds GJ, Sutton MA. 2009. The impact of nitrogen deposition on carbon sequestration by European forests and heathlands. Forest Ecology and Management 258:1814-23.

Dungait JAJ, Hopkins DW, Gregory AS, Whitmore AP. 2012. Soil organic matter turnover is governed by accessibility not recalcitrance. Global Change Biology 18:1781-96.

Franklin O, Högberg P, Ekblad A, Ågren GI. 2003. Pine forest floor carbon accumulation in response to $\mathrm{N}$ and $\mathrm{PK}$ additions: bomb ${ }^{14} \mathrm{C}$ modelling and respiration studies. Ecosystems 6:644-58.

Geisseler D, Horwath WR. 2009. Relationship between carbon and nitrogen availability and extracellular enzyme activities in soil. Pedobiologia 53:87-98.

Gordon C, Wynn JM, Woodin SJ. 2001. Impacts of increased nitrogen supply on high Arctic heath: the importance of bryophytes and phosphorus availability. New Phytologist 149:461-71.

Gornall JL, Jónsdóttir IS, Woodin SJ, Van der Wal R. 2007. Arctic mosses govern below-ground environment and ecosystem processes. Oecologia 153:931-41.

Gough L, Hobbie SE. 2003. Response of moist non-acidic tundra to altered environment: productivity, biomass, and species richness. Oikos 103:204-16.

Gough L, Wookey PA, Shaver GR. 2002. Dry heath arctic tundra responses to long-term nutrient and light manipulation. Arctic, Antarctic and Alpine Research 34:211-18.

Harsem Ø, Eide A, Heen K. 2011. Factors influencing future oil and gas prospects in the Arctic. Energy Policy 39:8037-45.

Hartley IP, Hopkins DW, Garnett MH, Sommerkorn M, Wookey PA. 2008. Soil microbial respiration in arctic soil does not acclimate to temperature. Ecology Letters 11:1092-100.

Hartley I, Hopkins D, Sommerkorn M, Wookey P. 2010. The response of organic matter mineralisation to nutrient and substrate additions in sub-arctic soils. Soil Biology and Biogeochemistry 42:92-100.

Henriksen TM, Breland TA. 1999. Nitrogen availability effects on carbon mineralization, fungal and bacterial growth, and enzyme activities during decomposition of wheat straw in soil. Soil Biology and Biochemistry 31:1121-34.

Hugelius G, Strauss J, Zubrzycki S, Harden JW, Schuur EAG, Ping CL, Schirrmeister L, Grosse G, Michaelson GJ, Koven CD, O’Donnell JA, Elberling B, Mishra U, Camill P, Yu Z, Palmtag J, Kuhry P. 2014. Estimated stocks of circumpolar permafrost carbon with quantified uncertainty ranges and identified data gaps. Biogeosciences 11:6573-93.

Jiang Y, Rocha AV, Rastetter EB, Shaver GR, Mishra U, Zhuang Q, Kwiatkowski BL. 2016. C-N-P interactions control climate driven changes in regional patterns of $C$ storage on the North Slope of Alaska. Landscape Ecology 31:195-213.

Koyama A, Kavanagh KL, Stephan K. 2010. Wildfire Effects on Soil Gross Nitrogen Transformation Rates in Coniferous Forests of Central Idaho, USA. Ecosystems 13:1112-26.
Kühnel R, Roberts TJ, Björkman MP, Isaksson E, Aas W, Holmén K, Ström J. 2011. 20-year climatology of $\mathrm{NO}_{3}{ }^{-}$and $\mathrm{NH}_{4}{ }^{+}$wet deposition at Ny-Ålesund, Svalbard. Advances in Meteorology 2011:1-10.

Lang SI, Cornelissen JHC, Klahn T, van Logtestijn RSP, Broekman R, Schweikert W, Aerts R. 2009. An experimental comparison of chemical traits and litter decomposition rates in a diverse range of subarctic bryophyte, lichen and vascular plant species. Journal of Ecology 97:886-900.

Lavoie M, Mack MC, Schuur EAG. 2011. Effects of elevated nitrogen and temperature on carbon and nitrogen dynamics in Alaskan arctic and boreal soils. Journal of Geophysical Research 116:G03013. https://doi.org/10.1029/2010JG001629.

Leitner S, Wanek W, Wild B, Haemmerle I, Kohl L, Keiblinger KM, Zechmeister-Boltenstern S, Richter A. 2012. Influence of litter chemistry and stoichiometry on glucan depolymerization during decomposition of beech (Fagus sylvatica L.) litter. Soil Biology and Biochemistry 50:174-87.

Lindo Z, Gonzalez A. 2010. The bryosphere: an integral and influential component of the Earth's biosphere. Ecosystems 13:612-27.

Liu L, Greaver TL. 2010. A global perspective on belowground carbon dynamics under nitrogen enrichment. Ecology Letters 13:819-28.

Mack MC, Schuur EAG, Bret-Harte MS, Shaver GR, Chapin FS. 2004. Ecosystem carbon storage in arctic tundra reduced by long-term nutrient fertilization. Nature 431:440-3.

Nowinski NS, Trumbore SE, Schuur EAG, MacK MC, Shaver GR. 2008. Nutrient addition prompts rapid destabilization of organic matter in an arctic tundra ecosystem. Ecosystems 11:1625.

Peñuelas J, Sardans J, Rivas-ubach A, Janssens IA. 2013. Human-induced nitrogen-phosphorus imbalances alter natural and managed ecosystems across the globe. Nature Communications 4:2934.

Pouliot R, Rochefort L, Gauthier G. 2009. Moss carpets constrain the fertilizing effects of herbivores on graminoid plants in arctic polygon fens. Botany 87:1209-22.

Reichstein M, Subke J, Angeli A, Tenhunen J. 2005. Does the temperature sensitivity of decomposition of soil organic matter depend upon water content, soil horizon, or incubation time? Global Change Biology 11:1754-67.

Schuur EAG, McGuire AD, Grosse G, Harden JW, Hayes DJ, Hugelius G, Koven CD, Kuhry P. 2015. Climate change and the permafrost carbon feedback. Nature 520:171-9.

Shaver GR, Chapin FSI. 1995. Long-term responses to factorial, NPK fertilizer treatment by Alaskan wet and moist tundra sedge species. Ecography 18:259-75.

Shaver GR, Johnson LC, Cades DH, Murray G, Laundre J, Rastetter EB, Nadelhoffer KJ, Giblin AE. 1998. Biomass and $\mathrm{CO}_{2}$ flux in wet sedge tundras: responses to nutrients, temperature and light. Ecological Monographs 68:75-97.

Shaver GR, Giblin AE, Nadelhoffer KJ, Thieler KK, Downs MR, Laundre JA, Rastetter EB. 2006. Carbon turnover in Alaskan tundra soils: effects of organic matter quality, temperature, moisture and fertilizer. Journal of Ecology 94:740-53.

Sinsabaugh RL, Carreiro MM, Repert DA. 2002. Allocation of extracellular enzymatic activity in relation to litter composition, $\mathrm{N}$ deposition, and mass loss. Biogeochemistry 60:1-24.

Sistla SA, Asao S, Schimel JP. 2012. Detecting microbial N-limitation in tussock tundra soil: implications for Arctic soil organic carbon cycling. Soil Biology and Biochemistry 55:78-84. 
Soudzilovskaia NA, van Bodegom PM, Cornelissen JHC. 2013. Dominant bryophyte control over high-latitude soil temperature fluctuations predicted by heat transfer traits, field moisture regime and laws of thermal insulation. Functional Ecology 27:1442-54.

Street LE, Shaver GR, Rastetter EB, van Wijk MT, Kaye BA, Williams M. 2012a. Incident radiation and the allocation of nitrogen within Arctic plant canopies: implications for predicting gross primary productivity. Global Change Biology 18:2838-52.

Street LE, Stoy PC, Sommerkorn M, Fletcher BJ, Sloan VL, Hill TC, Williams M. 2012b. Seasonal bryophyte productivity in the sub-Arctic: a comparison with vascular plants. Functional Ecology 26:365-78.

Street LE, Burns NR, Woodin SJ. 2015. Slow recovery of High Arctic heath communities from nitrogen enrichment. New Phytologist 206:682-95.

Turetsky MR. 2003. The role of bryophytes in carbon and nitrogen cycling. Bryologist 106:395-409.

Turetsky MR, Bond-Lamberty B, Euskirchen E, Talbot J, Frolking S, McGuire AD, Tuittila E-S. 2012. The resilience and functional role of moss in boreal and arctic ecosystems. New Phytologist 196:49-67.
Walker DA, Raynolds MK, Daniëls FJA, Einarsson E, Elvebakk A, Gould WA, Katenin AE, Kholod SS, Markon CJ, Melnikov ES, Moskalenko NG, Talbot SS, Yurtsev BA, Team CAVM. 2005. The Circumpolar Arctic vegetation map. Journal of Vegetation Science 16:267-82.

Wieder WR, Cleveland CC, Smith WK, Todd-Brown K. 2015. Future productivity and carbon storage limited by terrestrial nutrient availability. Nature Geoscience 8:441-5.

Winther M, Christensen JH, Plejdrup MS, Ravn ES, Eriksson ÓF, Kristensen HO. 2014. Emission inventories for ships in the Arctic based on satellite sampled AIS data. Atmospheric Environment 91:1-14.

Yi S, Woo MK, Arain MA. 2007. Impacts of peat and vegetation on permafrost degradation under climate warming. Geophysical Research Letters 34:1-5.

Zaehle S, Dalmonech D. 2011. Carbon-nitrogen interactions on land at global scales: current understanding in modelling climate biosphere feedbacks. Current Opinion in Environmental Sustainability 3:311-20.

Zamin TJ, Bret-Harte MS, Grogan P. 2014. Evergreen shrubs dominate responses to experimental summer warming and fertilization in Canadian mesic low arctic tundra. Journal of Ecology 102:749-66. 